\title{
Political Socialization and the Future of Politics
}

\author{
Marc Hooghe \\ Department Politieke Wetenschappen, University of Leuven, E. van Evenstraat 2B, B-3000 \\ Leuven, Belgium. \\ E-mail: Marc.Hooghe@soc.kuleuven.ac.be
}

It is clear that generational replacement is one of the main driving forces for social and political change in liberal democracies. While there is considerable consensus about the observation that the political attitudes and behaviors of young people differ significantly from those of earlier cohorts, there is disagreement about how this observation should be interpreted. Some authors worry about the decline of participation and trust among young people; others herald their tolerance and critical attitudes. In this introduction, it is argued that, because of this generational replacement mechanism, youth studies offer us a glimpse of the future evolution of western political systems. If the differences that are currently being observed persist into later parts of the life cycle, this implies that political systems will have to find a way to adapt to a more critical and distant citizenry.

Acta Politica (2004) 39, 331-341. doi:10.1057/palgrave.ap.5500082

Keywords: political socialization; youth studies; generational replacement; political participation

In the field of political survey research, it rarely occurs that there is an acrossthe-board consensus about the basic characteristics of the phenomena being studied. Nevertheless, in recent years a remarkable consensus has grown over the observation that in most Western societies, the political orientations of younger age cohorts differ in fundamental ways from those embodied by their predecessors. Either with regard to political behavior, participation, attitudes or norms and values, current opinion research tends to show marked differences between generations. As a result, generational replacement is generally considered to be a key process driving social and political change with respect to attitudes toward political institutions.

Opinions differ, however, on how exactly this shift should be conceptualized, and what it spells out for the future of democracy. Some authors have expressed concern about what they perceive to be a lack of democratic commitment and engagement among younger age cohorts. One of the most important findings in this respect is the fact that they are less likely to cast a vote during elections. In a number of Western democracies, voter turnout is in decline, and there is some evidence that this phenomenon is particularly acute 
among the younger generations. Again, however, various answers are being offered as to why this might be the case (Plutzer, 2002; Blais et al., 2004; Franklin et al., 2004). While some authors cite political cynicism, a lack of political interest or a lesser sense of civic obligation, others point to institutional arrangements that have a negative impact on the willingness of young people to vote. Voter registration requirements, the lack of ideological debate, or the perceived lack of a real alternation in the political elite might have as an effect that especially young people no longer want to participate in elections. Turnout figures are not the only indicators corroborating the observation that the relation between young people and institutionalized party politics is under serious stress. Feelings of partisanship and party identification have traditionally correlated positively with age; because of life cycle effects, party identification tends to become more ingrained in people as they get older. But even so, the slope of the curve has become steeper during the last decade, as young people have tended to eschew traditional party politics altogether (Dalton, 2002, 31). In various countries, the youth sections of political parties - traditionally important channels for recruitment into mainstream party politics - are rapidly losing members and are almost on the brink of disappearing (Hooghe et al., 2004). There is no consensus, however, on the question of how these trends should be interpreted. Some authors view these figures and trend lines as just one manifestation of a more general trend toward a less engaged citizenry. According to these researchers, young people are not just less interested in voting and in party politics, they are also less likely to get engaged in various other forms of civic engagement, and they are more distrusting toward political institutions or their fellow citizens. Putnam (2000) argues that generational replacement is one of the key mechanisms to explain the decline of social capital in US society. Young people do not just refrain from party politics, but also from civic engagement, membership of voluntary associations and various forms of formal and informal interaction. Not only are they less civicly engaged than older age groups, but they are also less likely to participate than the generation of their parents were 20 or 30 years ago. Some studies indeed seem to confirm the assertion that younger age cohorts tend to be more distrustful and less engaged in civic activities (Rahn and Transue, 1998).

In sharp contrast to this more pessimistic line of research, other authors consider this decline literature to be a rather one-sided view of how young people interact with the political system. Although we have accumulated sufficient evidence by now about the strained relation between young age cohorts and traditional political institutions; this should not be taken to mean that young people have lost interest in politics and public affairs. Rather, they prefer more informal ways of participating in politics, espousing more lifestylerelated and loosely structured forms of civic engagement (O'Toole et al., 2003). 
Often these forms of engagement that range from wearing political signs and logos, making shopping decisions based on political considerations, signing petitions and spontaneously attending rallies or political concerts are not even picked up or acknowledged in mainstream political science research (Gauthier, 2003). One could even turn the argument around, by claiming that younger generations are actually more democratically minded than older generations are or were. Results from the World Value Surveys seem to demonstrate that younger age cohorts adhere more strongly to democratic norms, as they are more tolerant and they tend to be more critical toward authoritarian and hierarchical institutions (Inglehart, 2003). Especially with regard to gender equality and tolerance towards a broad variety of lifestyles, younger age groups certainly are more open-minded than the generation of their parents used to be, and this too, can be interpreted as the continued spread of democratic ideals (Inglehart and Norris, 2003). In this respect, younger age groups function as the vanguard of a new generation of 'critical citizens', who tend to be more skeptical about the performance of political institutions, but who are, at the same time deeply committed to democratic norms and to tolerance (Norris, 1999).

An implicit assumption in most of the current literature on youth and politics is that youth studies have a wider relevance for the field of political science in general. Structural social changes, like secularization, globalization or individualization are expected to have an impact on the political attitudes and behaviors of the entire population. However, for adults these effects are mitigated by the fact that their initial political orientations were shaped decades ago, and to some extent these orientations are carried along over the entire life cycle (Jennings, 1987). For younger people, the effect of these structural transformations is not just easier to detect and to observe, it might also have a stronger impact as they were experienced in the formative period of their lives. As Franklin $(2004,216)$ reminds us: 'The future lies in the hands of young people. Young people hold the key to the future because they are the ones who react to new conditions. Older people are, on the whole, too set in their ways to be responsible for social or political change, so most long-term change comes about by way of generational replacement'.

Over the past couple of years, an intense debate has been going on in the field of political participation studies about the question whether civic and political engagement, and political trust are indeed caught in a downward spiral, as some pessimistic authors would have it (for a review, see Stolle and Hooghe, 2005). Within this debate, a lot of research attention is focused on young people, as they are most likely to be affected by this social trend. It is assumed that if we can find out more about the political orientations of young people, this already offers us a glimpse of the future that lies ahead. A clear illustration of this logic can be found in the recent work by Russell Dalton on the evolution of political trust. Dalton $(2004,93)$ notes that back in the 1950 s, 
multivariate analysis showed a negative relation between age and trust (indicating that older people are significantly more distrustful). In the most recent studies, however, this relation has been turned around, as younger age cohorts now are clearly more distrustful than older respondents. According to Dalton $(2004,94)$, this finding allows us some grounds for speculation about future trends: "the young are now more likely to display lower levels of political trust and greater cynicism towards politicians and political institutions. Members of 'generation X', for example begin their political experience as cynics - and these sentiments might only strengthen with continued experience with everyday politics. The normal process of demographic turnover may therefore produce continued downward pressure on political support in the years ahead.' To put it differently: the basic assumption in this line of research is that cohort effects will prove to be more powerful than age or period effects.

One might consider this a rather instrumental use of youth studies: in this kind of research young people are used as a miner's canary. It is assumed that if there is any poison in the air of democracy, young people will be the first to detect the danger. Obviously, various objections against this instrumental use of youth studies can be formulated: it could be argued that the political orientations of young people should be understood in their own right, and not just as a convenient early detection mechanism (Gauthier, 2003). However, we might also express a more methodological concern: using young age cohorts this way only makes sense if we can safely assume that they will continue their current political orientations into the future, once they have reached adulthood. This amounts to what has been called a 'persistence model', essentially claiming that 'the residues of preadult learning persist through life, perhaps even hardening with time' (Sears and Levy, 2003, 78). In some cases, this persistence has indeed been demonstrated; with regard to partisanship and party identification, for example, early orientations proved to have strong and lasting effects (Ventura, 2001). As Green et al. (2002, 107-108) summarize it: 'The influences of the political environment are most noticeable among new voters, whose partisan attachments often bear the stamp of the political Zeitgeist that prevailed when they reached voting age or became naturalized citizens'. In this view, primary socialization experiences tend to produce persistent effects, which are only marginally influenced by later socialization experiences. This concept of persistent political self-identification is of course nothing new, as it already was formulated in Karl Mannheim's classical thesis on the creation of 'political generations' by what he called generation-defining events.

The recent research on voting behavior, too, supports the claim that once a behavioral pattern is established, for example, the first time young people are eligible to vote, they will easily persist in this behavioral pattern in the elections 
ahead (Plutzer, 2002; Franklin et al., 2004). Once the habit of voting has been acquired, it requires only a minimal investment of time, attention and resources to continue the pattern; for a first-time voter, however, this investment is more substantial. It has to be kept in mind, though, that this persistence hypothesis has also been challenged, by various authors arguing that socialization experiences later on in the life cycle, and age- and period effects might have equally powerful influences. Furthermore, it is likely that the persistence hypothesis might be valid for some orientations and some forms of behavior, while it is less successful explaining other attitudes. The validity of the persistence thesis, therefore, remains an open empirical question, despite the fact that current research supports the occurrence of persistence, at least with regard to some attitudes (Sears and Levy, 2003).

The renewed interest in the political orientation of young age cohorts has resulted in a revival of political socialization studies (Galston, 2001; Sapiro, 2004). If young people indeed hold the key for the future functioning of our political systems, it becomes all the more important to understand how and where they acquire their knowledge about politics, and how they are socialized into political attitudes. As Sapiro (2004) points out, current socialization research is fundamentally different from the one that emerged in the 1950s and 1960s. In that earlier era, it was emphasized that socialization should serve as a mechanism to ensure political stability. In this respect, political socialization studies were quite heavily influenced by the Parsonian paradigm. In Parsons' theory, social systems maintain their stability and they safeguard their survival by an intensive socialization process whereby the prevailing values underlying the system are being interiorized by new age cohorts. In Parsons' world, socialization ensures stability, it does not lead to social change or modernization, and the same can be said about most of the socialization research of the 1950s and 1960s. A rather typical example of this traditional view on political socialization would be a French study conducted in the early 1960s. The researchers were mostly interested in the question of whether young people knew the national anthem and the name of the president, while they also expressed concern about the rather lenient attitude of young children toward traitors to the country (Roig and Billon-Grand, 1968). Current socialization research, in contrast, focuses on the question where and how young people acquire political knowledge, whether they are interested in politics, and on whether they engage, or intend to engage in social and political life (Hooghe and Stolle, 2004; Torney-Purta, 2004). The scope of socialization experiences being considered has been expanding just as well: while in the 1960s there was a tendency to concentrate research efforts on the impact of parents and schools; now voluntary associations, mass media, peer groups and informal interactions gradually come more into focus in socialization research. 
Using the study of young people to obtain some indications about the likely evolution of political systems in Western societies only makes sense if a number of conditions are being met. First of all, it has to be made clear that there is indeed a genuine and profound difference between younger and older age cohorts. Cross-sectional data cannot be used for this purpose, as they do not allow for the disentangling of age from generational effects. The fundamental question is not whether young people differ from older people, but whether the current cohort of young people differs from earlier youth cohorts, in the 1950s and 1970s, or even earlier. This implies we need time series, and preferably, panel data. Once we know that younger age cohorts indeed developed specific characteristics, the second question becomes how we could explain them. In a number of countries, civic education has gained new prominence in the school curricula, while civics courses in general have become much more practice oriented in the past decades (APSA, 2004). Other factors, whether they are school related or not, however, might have an equally important effect on young people's political orientations.

A third question concerns the consequences of our findings: we can assume that young people relate differently to the political system than previous cohorts used to do. At this moment, however, we do not know whether, and how, liberal political systems will find a way to adapt to the spread of a more critical and distant citizenry. From a more procedural point of view, one could argue that we should not be concerned about the fact that young people tend to be more distant and critical vis-à-vis the political system and their governments, for example, with regard to political parties. As long as they continue to participate in the democratic process (the minimum requirement here would be voting), these new attitudes do not necessarily spell trouble for democratic politics. To substantiate that claim we would need some evidence here that the attitude of young people indeed leads to lower turnout figures, to drastically less informed voters, to more cynical citizens or less engaged community members.

Finally, we would also need some proof of the persistence thesis. For a number of indicators, it is quite evident that young people on average score lower than older people do. Young people are not yet integrated into the labor market, they do not yet have children of their own and probably they do not own their own family house. All of this implies that they are less likely to be connected to civil society and to politics: they are less likely to be members of trade unions, parents' committees or neighborhood watch associations. Furthermore, because of prolonged education, this youth phase has a tendency to become extended in Western societies. These well-known life cycle effects are no reason for concern - clearly young people are known to be less engaged throughout several generations. The picture becomes different, however, if we gather some evidence that this passivity is likely to persist into the future, when 
youngsters have reached adulthood. In sum, these four questions amount to a number of fundamental queries: is the difference really there, why is it there, what are its consequences, and is it likely to remain there in the future? These are the four questions that we set out to answer in this special issue.

First, M. Kent Jennings and Laura Stoker present unique evidence about the trends in social engagement and generalized trust among the US population. They build their analysis on the results from the Youth-Parent Socialization panel that started in 1965, with subsequent interview waves in 1973, 1982 and 1997. A unique feature of this panel study is not just the extraordinary time span it covers, but also the fact that in 1965 the parents of the respondent were included in the study and in 1997 the children of the original respondents, resulting in a data set that comprises information on three generations across a 3 -decade time span. Their analysis demonstrates that especially the youngest age cohort seems affected by a decline in social trust. While in 1965, almost two-thirds of the respondents (aged 17 at that time) agreed with the statement that most people can be trusted, 32 years later, only one-third of the children of these respondents shares this trusting outlook (while their parents remained just as trusting as in 1965). Interestingly, however, this analysis shows that the youngest age cohort, the so-called 'Generation X', born after 1970, seems responsible for the bulk of the decline in trust and engagement, and not the earlier generation of baby-boomers, as is argued in some other studies. The youngest age cohorts, however, not only participate less, but also in a more sporadic manner, fluctuating more easily over time. Jennings and Stoker, however, also warn us about all-too-easy extrapolations: they find strong age and life cycle effects, both with regard to trust as with regard to engagement. The occurrence of these effects implies that one should be very careful in assuming that young people will simply continue their current behavioral and attitudinal pattern into the future.

The second article in this issue is based on an equally unique data set. Judith Torney-Purta, Carolyn Henry Barber and Wendy Klandl Richardson use the IEA Civic Education survey (where Torney-Purta was the principal investigator) to ascertain how we can explain the emergence of trust and engagement among 14 year olds in various national settings. Their analysis demonstrates that understanding the emergence of young people's political and civic orientation depends on the interplay between micro- and macro-level explanations. At the micro-level, the propensity to discuss politics with parents proved to have a strong effect on the willingness to participate. This finding confirms some of the older assumptions about the intergenerational transmission of political interest and political orientation from parents to their children. At the macro-level Torney-Purta et al. find intriguing differences between stable democracies and newly emerging democratic systems. In countries where political institutions do not always live up to democratic expectations, children 
are less likely to express political trust, and they are also more doubtful about whether they will participate in political life once they become adults. This can be explained by invoking a threshold model: it is only when political systems cross a certain threshold of trustworthiness and performance that young people are actually likely to develop feelings of political or institutional trust. Finally, this analysis also shows that schools matter, not just with regard to the formal inclusion of civic education in their curricula, but also in the ways that they encourage their pupils to get informed and to engage themselves in various forms of participation.

In the Torney-Purta et al. article, the 14 year olds are questioned about their likelihood to vote, once they become enfranchised. However, we also have some evidence about what actually happens with regard to voter turnout among young people. The research team, responsible for the Canadian election studies has already demonstrated that the youngest voters (i.e., those born after 1970) are responsible for most of the decline in voter turnout in Canada since the late 1980s (Blais et al., 2004). Differences are indeed remarkable: while turnout stands at 71 percent for those born before 1970, is just 44 percent for those born after 1970. In this article however, Daniel Rubenson, André Blais, Patrick Fournier, Elisabeth Gidengil and Neil Nevitte build on these findings to explain why exactly young people refrain from participating in the 2000 federal elections in Canada. Contrary to what is too often assumed, this age gap is not being caused by the spread of feelings of cynicism among young people, and, at least in this Canadian study, young people do not seem to be more cynical about politics than older citizens. What does seem to matter, however, are political interest and political knowledge, as both of these indicators clearly show lower scores for young people. This finding confirms the worries of the pessimistic views on civic decline in the young generation, as their participation in the democratic process seems threatened. It would be important to test whether this trend holds in other countries beyond the Canadian or the North American context. These findings also shift the question for future research, as Rubenson et al. indicate in their concluding remarks: 'it remains to be explained why younger people are less interested in and informed about politics than their older fellow citizens'. Furthermore, the findings in this article call for further research to find out whether a similar pattern of political disengagement among young people might be found in other countries too.

Finally, we turn to the fourth piece of the puzzle: will these differences prove to be persistent, and will they determine the political culture of Western democracies? In order to answer this question, Dietlind Stolle and Marc Hooghe test the persistence hypothesis with an analysis of the Youth-Parent Socialization Study that was also used in the Jennings/Stoker article. Two mechanisms are being tested in this analysis: first, a network mechanism, 
assuming that those who are active in associations already at an early age will remain active later on in life, as they have become members in politicized networks. Second, an attitudinal mechanism might ensure that civic attitudes shaped at an early age either in associations or as a result of other experiences will persist into later life. The main finding of this analysis is that generalized trust should be regarded as a persistent attitude, with a high degree of stability between adolescence and adulthood. The analysis, however, also produced support for the occurrence of a network effect: those respondents who joined selected youth participation were more active as adults, although the stability with regard to participation levels proved to be less outspoken than with regard to trust. The results, presented by Stolle and Hooghe are in line with some of the recent research on generalized trust, showing that this attitude is shaped quite early in life, and proves to be rather stable, despite obvious age and life cycle effects. Their validation of the persistence thesis heightens the relevance of the research on young people's orientations; we can assume that if young people are less trusting and less engaged than earlier cohorts were, this difference will remain persistent when these cohorts reach adulthood. At the same time, the article reveals that the study of the sources of civicness must include experiences in the early life phase.

The articles in this special issue make clear that political socialization stands at the heart of political science, and should not be regarded as a 'soft edge' of the discipline, inhabited only by people who want to get involved with schools and children, as is often assumed. Despite the fact that in most departments of political science, political socialization is not institutionally embedded (Sapiro, 2004), it is clear that socialization studies have become an important subdiscipline of political science, one that allows us to develop interesting cross-links with disciplines such as education and psychology. In this respect, we are quite proud to be able to include in this issue two articles by some of the 'arch-parents' of political socialization research, M. Kent Jennings and Judith Torney-Purta, both of whom have, to a large extent, shaped socialization research, ever since their first steps in this field (Jennings, 1968; Hess and Torney, 1967).

In her review article, Virginia Sapiro $(2004,4)$ stresses the wider relevance of political socialization studies: 'Surely the questions of how people develop their basic sets of political skills, orientations, and practices, and how their experiences shape their politics are as pressing as ever'. These questions have acquired a new relevance, now it seems clear that our democratic systems are 'in flux' (Putnam, 2002), with a trend toward lower degrees of partisanship, increasing voter volatility, a greater reliance on electronic mass media to obtain political information, and probably (although the evidence is not yet entirely conclusive on these two accounts) lower turnout figures and lower institutional trust. More informal and flexible forms of engagement and involvement, on the other hand, seem to on the rise, but thus far it remains questionable which 
political impact of these new forms will have. Dalton et al. (2003, 273, 274) note: 'we are ready to cautiously assert that the sum of the changes across multiple governmental arenas does constitute a significant change in policy processes and in assumptions about who should be included in policy decisions (...) A new model of democracy is evolving. The contemporary democratic process requires more of its citizens. It also challenges politicians and bureaucrats to figure out what it means to move past a trustee model of politics without abdicating political leadership'. As Dalton et al. admit: at this moment of research, we have only a vague idea of what the contours of this new type of democracy will be and how it will function. The articles in this issue strongly suggest that we can find out more about these contours by looking at what goes on in schools, youth associations, and probably even by looking at our own students. By doing so, we do discover that there is indeed quite some potential for a further democratization of our political systems, as Dalton et al. proclaim. But we can also observe that the pitfalls on the way certainly are not negligible.

\section{Acknowledgements}

A preliminary version of the articles in this special issue was first presented at the workshop 'Citizenship on Trial. Interdisciplinary Perspectives on Political Socialization of Adolescents', held at McGill University, Montreal, on 20-21 June, 2002. The workshop was made possible by the generous financial support of the Institut d'études européennes/Institute for European Studies (Université de Montréal/McGill University), and the Faculty of Arts and the Political Science Department of McGill University. A special word of thanks to Claudia Carravetta and Lisa Nevens for their help in organizing the event. Furthermore, we would like to thank the participants in this workshop, and the editor, for their critical comments on the earlier versions of the articles.

\section{References}

APSA Standing Committee on Civic Education and Engagement (2004) Toward a Political Science of Citizenship, Washington, DC: American Political Science Association.

Blais, A., Gidengil, E., Nevitte, N. and Nadeau, R. (2004) 'Where does turnout decline come from', European Journal of Political Research 43: 221-236.

Dalton, R. (2002) 'The Decline of Party Identifications', in R. Dalton and M. Wattenberg (eds.) Parties without Partisans, Oxford: Oxford University Press, pp. 19-36.

Dalton, R. (2004) Democratic Challenges, Democratic Choices, The Erosion of Political Support in Advanced Industrial Democracies, Oxford: Oxford University Press.

Dalton, R., Cain, B. and Scarrow, S. (2003) 'Democratic Publics and Democratic Institutions', in B. Cain, R. Dalton and S. Scarrow (eds.) Democracy Transformed? Expanding Political Opportunities in Advanced Industrial Democracies, Oxford: Oxford University Press, pp. 250-275. 
Franklin, M. (2004) Voter Turnout and the Dynamics of Electoral Competition in Established Democracies since 1945, Cambridge: Cambridge University Press.

Franklin, M., Lyons, P. and Marsh, M. (2004) 'Generational basis of turnout decline in established democracies', Acta Politica 39(2): 115-151.

Galston, W. (2001) 'Political knowledge, political engagement, and civic education', Annual Review of Political Science 4: 217-234.

Gauthier, M. (2003) 'The inadequacy of concepts, the rise of youth interest in civic participation in Quebec', Journal of Youth Studies 6(3): 265-276.

Green, D., Palmquist, B. and Schickler, E. (2002) Partisan Hearts and Minds, Political Parties and the Social Identity of Voters, New Haven: Yale University Press.

Hess, R. and Torney, J. (1967) The Development of Political Attitudes in Children, Chicago: Aldine.

Hooghe, M. and Stolle, D. (2004) 'Good girls go to the polling booth, bad boys go everywhere, Gender differences in anticipated political participation among US 14 year olds', Women and Politics 26(3), in press.

Hooghe, M., Stolle, D. and Stouthuysen, P. (2004) 'Head start in politics, the recruitment function of youth organizations of political parties in Belgium (Flanders)', Party Politics 10(2): 193-212.

Inglehart, R. (ed.) (2003) Human Values and Social Change. Findings from the Values Survey, Leiden: Brill.

Inglehart, R. and Norris, P. (2003) Rising Tide. Gender Equality and Cultural Change Around the World, Cambridge: Cambridge University Press.

Jennings, M.K. (1968) 'Parental grievances and school politics', Public Opinion Quarterly 32(3): 363-378.

Jennings, M.K. (1987) 'Residues of a movement, the aging of the American protest generation', American Political Science Review 81: 367-382.

Norris, P. (ed.) (1999) Critical Citizens, Global Support for Democratic Governance, Oxford: Oxford University Press.

O’Toole, T., Lister, M., Marsh, D., Jones, S. and McDonagh, A. (2003) 'Tuning out or left out? Participation and non-participation among young people', Contemporary Politics 9(1): 45-61.

Plutzer, E. (2002) 'Becoming a habitual voter, Inertia, resources, and growth in young adulthood', American Political Science Review 96(1): 41-56.

Putnam, R. (2000) Bowling Alone. The Collaps and Revival of American Community, New York: Simon and Schuster.

Putnam, R. (ed.) (2002) Democracies in Flux. The Evolution of Social Capital in Contemporary Society, Oxford: Oxford University Press.

Rahn, W. and Transue, J. (1998) 'Social trust and value change, the decline of social capital in American youth, 1976-1995', Political Psychology 19: 545-565.

Roig, C. and Billon-Grand, F. (1968) La socialisation politique des enfants, Paris: Armand Colin.

Sapiro, V. (2004) 'Not your parents' political socialization, Introduction for a new generation', Annual Review of Political Science 7: 1-23.

Sears, D. and Levy, S. (2003) 'Childhood and Adult Political Development', in D. Sears, L. Huddy and R. Jervis (eds.) Oxford Handbook of Political Psychology, Oxford: Oxford University Press, pp. 60-109.

Stolle, D. and Hooghe, M. (2005) 'Inaccurate, exceptional, one-sided or irrelevant? The debate about the alleged decline of social capital and civic engagement in Western societies', British Journal of Political Science 35(1), in press.

Torney-Purta, J. (2004) 'Adolescents' political socialization in changing contexts: an international study in the spirit of Nevitt Sanford', Political Psychology 25(3): 465-478.

Ventura, R. (2001) 'Family political socialization in multiparty systems', Comparative Political Studies 34(6): 666-691. 